\title{
UNDERSTANDING THE INFLUENCE OF MEDIA RICHNESS IN DEVELOPING CUSTOMER TRUST, COMMITMENT AND LOYALTY
}

\author{
NORAIHAN MOHAMAD
}

School of Hospitality and Creative Arts, Management and Science University, University Drive, Off Persiaran Olahraga, Section 13, 40100, Shah Alam, Selangor

*Corresponding author: noraihan_mohamad@msu.edu.my

Submitted final draft: 12 May $2020 \quad$ Accepted: 18 August $2020 \quad$ http://doi.org/10.46754/jbsd.2020.09.003

\begin{abstract}
Customer loyalty aids businesses by increasing their ability to face competition, reduce marketing costs, provide publicity through word-of-mouth, and boost sales and profits in the long term. Prior studies consistently revealed that brand is an antecedent of customer trust and commitment, and it nurtures loyalty. However, today, the customers' perception and attitude towards businesses have changed. Customer loyalty can be developed using various antecedents. Drawing upon the Media Richness Theory (MRT), this study aims to identify the effects of integrating print, online and face-to-face media in developing customer trust, commitment and loyalty. A cross-sectional survey was conducted among customers who purchased computer products in a particular shop. A total of 295 respondents were selected based on purposive and systematic random sampling techniques. Partial Least Square-Structural Equation Modelling (PLS-SEM) was employed to test the hypothesized model. The results show that media richness, through the integration of print, online and face-to-face communication, may significantly affect trust and customer loyalty. In conclusion, the research findings indicate that the the integration of various media may help customers make the right purchase decision. This study contributes to MRT by expanding it from the perspective of consumer behaviour. In practical terms, the findings provided important information to help ensure business sustainability and continuity.
\end{abstract}

Keywords: Consumer, behaviour, media richness theory, PLS-SEM, loyalty

\section{Introduction}

Today's vigorous growth in business underlines the need for each organisation to be able to face its competitors headon. Various promotional activities and marketing strategies need to be initiated to retain existing customers and expand the business. Therefore, business survival depends largely on the ability to remain competitive. This ability is developed through two main approaches, namely building relationships with new customers and transforming existing ones into loyaltybased relationships. Building loyalty among existing customers is more effective as it saves time, reduces costs and helps offset the focus on meeting customers' needs
(Berezan et al., 2016; Bulut \& Karabulut, 2018; Casado-Diaz et al., 2020).

Building customer loyalty is a strategy that provides long term advantages to businesses. Just by stepping up positive communication through word-of-mouth (WOM), sales and profits can be boosted as more people will be eager to try out the company's products (Berezan et al., 2016; Bulut \& Karabulut, 2018; Casado-Diaz et al., 2020). Customer loyalty demonstrates key catalytic factors that explain the longterm relationship with businesses. These are attested by repeat sales, increase in purchasing frequency, recommendation to other potential customers, price tolerance and of positive reviews through WOM (Sudaria et al., 2019). 
Literature review reveals that both trust and commitment are important predictive factors for customer loyalty (Morgan \& Hunt, 1994; Bulut \& Karabulut, 2018; Han et al., 2018; Mainardes \& Cardoso, 2019; Giao et al., 2020). Previous studies also focused on the product brand as an antecedent affecting customer trust and commitment, consequently leading to the building of customer loyalty (Lee et al., 2019; Giao et al., 2020; Khoa, 2020; Kim et al., 2020).

However, shifts in today's business landscape have concomitantly changed customers' perception and experience of a business. This explains the role of various factors in influencing loyalty to business organizations. Customer loyalty and trust can be developed through other antecedents apart from product brand. Examples include the salesperson's attitude, location of business premises, product quality, service quality, media and marketing communication, as well as customer knowledge and experience (Morgan \& Hunt, 1994; Gruner et al., 2019; Khoa, 2020; Kim et al., 2020).

Based on the Media Richness Theory (MRT), this study accordingly identified the influence of the integration of richness from different kinds of media, such as flyers (print), social media (online) and role of a salesperson (face-to-face communication), as antecedents of customers' purchasing decision and building their loyalty towards a business. The basic principle of MRT is to identify the effectiveness of media use on an individual's work performance in implementing organisational tasks (Daft \& Lengel, 1984). MRT assumes that each media has its own richness attribute in executing communication tasks. These attributes will determine the media's effectiveness in conveying information. The theory also suggests that the communication process must take into account the types of media machinery that will be deployed to produce effective communication (taskmedia fit). Media with a higher degree of richness are better suited to convey heavy and complex messages, while simple and easy messages require media with a lower degree of richness in information.

Despite the existence of traditional media, the roles and power of social media as an interactive information bank also encourage customers' high dependency on that media, including as an aid in making purchasing decisions. The integration of traditional and new media is instrumental in forming consumer perception and making an informative purchase decision. Therefore, this research seeks to elaborate on the influence of the integration of media richness between traditional and new media, specifically print, online and faceto-face communications, as an antecedent of customer trust and its subsequent effect on commitment and loyalty to business.

To understand customer loyalty, this study measured their perception and behaviour in purchasing computer products at a selected enterprise.

By focusing on one business enterprise, the customer's perception and behaviour may be measured from the same perspective. To obtain customers' near-accurate perception of the business, a self-administered questionnaire was given to respondents immediately after they purchased a product from the shop.

\section{Customer Loyalty}

Customer loyalty constitutes attitudes and behaviour in building a long-term relationship with businesses (Morgan \& Hunt, 1994; Khoa, 2020; Saini \& Singh, 2020). The basis of loyalty is the relationship between the buyer and the seller, which subsequently builds the customers' perceptions and emotions, hence determining their future actions. Customer loyalty has been defined differently based 
on three perspectives. First, loyalty may be measured based on repeat and frequency of purchases (Saini \& Singh, 2020). Second, loyalty is viewed as the customers' attitude in committing to undertake a purchase (Day, 1969; Khoa, 2020). Third, loyalty is defined as the combination of attitude and behaviour of customers (Nguyen et al., 2013; Khoa, 2020).

It is erroneous to define loyalty solely from the behavioural perspective because, without action, purchases only takes place due to facility, normalcy and pressure from products and other businesses (Nguyen et al., 2013; Saini \& Singh, 2020). Day (1969) regarded behaviour-based loyalty as false loyalty because behaviour does not take commitment into account. The attitudinal perspective will ensure that the customerbusiness relationship develops in the long term because the customer is committed to purchasing from the business, willing to engage in positive WOM and recommend the business to others, and showing tolerance where pricing is concerned (Day, 1969; Morgan \& Hunt, 1994; Nguyen et al., 2013; Khoa, 2020).

The discussion above explains that there is a relationship between attitudinal and behavioural perspectives. Attitude sans behaviour will not produce loyalty since there is no purchasing action, while behaviour without attitude indicates false loyalty. Combining both behavioural and attitudinal aspects in expounding customer loyalty is more accurate as loyalty may be described as stemming from the customer's deep interest and culminating in actual action (Nguyen et al., 2013; Khoa, 2020). Drawing upon this observation, this research defines customer loyalty as their attitude and behaviour in making repeated purchases, providing positive WOM, and showing price tolerance and profound interest to interact with the business in the long term.

\section{Media Richness}

The media provides key marketing platforms for businesses. They disseminate information and raise awareness about a product, besides influencing users to respond positively through the elements of persuasion. The cues in communication, such as speech, gestures, pictures, audio, videos and texts messages, are elements of media richness that affect users' cognitive and affective attitudes. MRT stipulates that media featuring different degrees of richness produce different communication effects (Daft \& Lengel, 1984). This research, therefore, seeks to identify the influence of media in different richness hierarchies on customer purchasing attitude and behaviour.

MRT identifies two factors that may affect information and indirectly impede the flow of communication. These factors are uncertainty and equivocality (Daft \& Lengel, 1984). Incomplete or wrong information provided by individuals will lead to uncertainty over the business' products and services. MRT postulates that uncertain messages conveyed through media have a low degree of richness, such as text messages and short writings. The pressure of this uncertainty may be reduced by using a media that allows the provision of more information.

Equivocality or ambiguity refers to the vagueness that causes individuals to make conflicting interpretations concerning a subject or situation. MRT suggests that ambiguous messages are communicated through media that have higher hierarchy of richness, such as face-to-face conversations, and its pressure may be reduced when individuals improve on their interpersonal communication skills. The MRT puts forward four media richness criteria for enhancing communication. They are: (1) ability to provide immediate feedback to individuals; (2) use of multiple cues for communication; (3) use of language that 
is understood by individuals concerned; and, (4) focus on personal needs of the individuals. Media that have a high degree of richness are those that fulfil all four criteria (Daft \& Lengel, 1984). Conversely, media that have a low degree of richness are those that fulfil parts of the criteria only.

This research employed three types of media, namely flyers, social media and the salesperson. They each represent print online and face-to-face media, respectively. They are commonly used by customers to seek information, acquire knowledge and enhance understanding about a product before making a purchase. Eventually, they will influence customers' purchasing attitude and behaviour at the businesses (Liu et al., 2014; Popp et al., 2015; Berezan et al., 2016; Sudaria et al., 2019; Kaur et al., 2020). Based on preceding discussion, the following hypotheses ( $\mathrm{H} 1$ and $\mathrm{H} 2)$ are formulated:

H1: Media richness positively and significantly affects customer trust towards a business.

H2: Media richness positively and significantly affects customer loyalty towards a business.

\section{Customer Trust}

Trust is a cognitive process that clarifies an individual's confidence and belief towards other parties. A customer's trust towards a business describes his belief and confidence in satisfying his consumption needs (Nguyen et al., 2013; Molinillo et al., 2017; Kim et al., 2020). Previous studies are consistent in showing trust as one of the significant elements in building customer loyalty (Morgan \& Hunt, 1994; Yang \& Wu, 2014; Molinillo et al., 2017; Kim et al., 2020). Customers with a high degree of trust tend to make repeated purchases, build long-term relationships with businesses, and show continuous support by providing positive WOM (Molinillo et al., 2017; Mainardes \& Cardoso, 2019).
The literature shows that there is a significant relationship between trust and loyalty among customers who have a positive perception of businesses $(\mathrm{Ou}$ et al., 2015; Kim et al., 2020; Saini \& Singh, 2020). Customer trust will become entrenched if they have positive experiences in a transaction, including experiences that are gained through the media (Bulut \& Karabulut, 2018; Mainardes \& Cardoso, 2019; Giao et al., 2020). Based on the foregoing discussion, the following hypotheses (H3 and $\mathrm{H} 4)$ are formulated:
H3: Customer trust positively and significantly affects customer commitment towards a business.

H4: Customer trust positively and significantly affects customer loyalty towards a business.

\section{Customer Commitment}

Customer commitment deals with profound willingness, readiness, determination and desire to build long-term relationships with businesses (Morgan \& Hunt, 1994; Han et al., 2018; Saini \& Singh, 2020). Commitment is displayed when customers considered their relationship with a business as important, valuable and beneficial. Strong emotional engagement between customers and businesses will reaffirm commitment. Customers with high commitment will be motivated to repeat their purchases, provide positive WOM, support the business' promotional activities, are not easily persuaded to switch products, and willing to recommend the businesses to other customers (Morgan \& Hunt, 1994; Han et al., 2018; Saini \& Singh, 2020). Previous studies indicated that there is a significant relationship between commitment and customer loyalty (Han et al., 2018; Iglesias et al., 2019; Kim et al., 2020). Thus, the following hypothesis (H5) is proposed:

H5: Customer commitment positively and significantly affects customer loyalty towards a business. 
Figure 1 is the research framework illustrates the relationship between predictive and endogenous constructs.

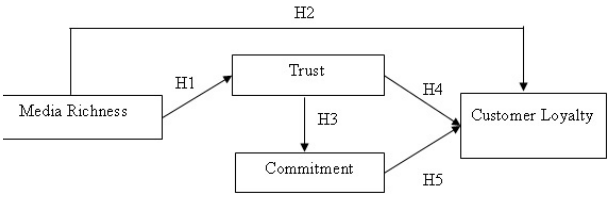

Figure 1: Research framework according to various hypotheses in building customer loyalty.

\section{Research Methods}

This study utilised a cross-sectional research design, which employed self-administered questionnaires to evaluate respondents' perception. The research analysis unit was individuals, specifically customers who bought computer products at a selected computer shop.

A total of 350 questionnaires were distributed. This sample size was necessary to meet the threshold for two statistical sampling procedures. First, concerning the G*Power software, this study needed at least 70 respondents as a statistical power of $80 \%$ was needed to detect R-square $\left(\mathrm{R}^{2}\right)$ values of at least 0.25 at a significant level $(\mathrm{p}<0.05)$ (Hair et al., 2014). Second, the minimum number of respondents needed was 50 , in line with the "10-times rule", where the sample size depended on the number of structural paths $(10 \times 5$ structural paths $=50$ respondents) that were pointing to a latent variable in the PLS structural model (Hair et al., 2014). Each structural path needs to be multiplied by 10 , and there were five structural paths in the model. Furthermore, for studies with many respondents, a sample size of between 100 and 200 was considered appropriate (Hair et al., 2006). Guided by these recommendations, 295 participants were selected as the sample size. This sample size was considered acceptable and valid for further analysis.
Since laptops, desktops, netbooks, tablets and printers were categorized as essential educational accessories, the respondents mostly comprised community members of educational institutions in the towns of Arau, Changlun, and Sintok, all straddling the northern states of Kedah and Perlis in Peninsular Malaysia. The educational institutions included Universiti Utara Malaysia (UUM), Universiti Malaysia Perlis (UniMAP), Politeknik Tuanku Syed Sirajuddin, Universiti Teknologi Mara (UiTM), Kolej Matrikulasi Kedah, Akademi Binaan Malaysia (ABM), Kolej Pertanian Malaysia, as well as several secondary schools.

The communities of these educational institutions were targeted because they were in districts in Kedah and Perlis, which were states that shared the same socio-economic characteristics and Central Business District (CBD). In this study, Changlun was referred to as the CBD since it served as the focal point of business activities in the area.

To investigate customer loyalty, a computer store in Changlun was selected as the point for data collection. The selection of the store was based on three specific criteria. First was the duration of its existence, which it had been since 1998 . Second, as gleaned from a preliminary study, was the store's popularity, especially among the members of the educational institutions in the area. Lastly, the shop had a considerable diversity of product brands to offer to its customers.

To obtain customers' perception of the business, a self-administered questionnaire was distributed to the target respondents immediately after they purchased a product. Data collection was conducted over two months, involving 295 respondents. To obtain the targeted number of respondents, a combination of purposive and systematic random sampling was employed. The purposive sampling technique was used to target a group of respondents from the 
educational institutions, who purchased computer products while the systematic random sampling technique was employed to avoid bias.

The questionnaire had two sections; Section A dealt with respondents' demography, media richness and media usage characteristics, whereas Section B contained constructs to evaluate customer trust, commitment and loyalty measured through a seven-point Likert Scale (1=strongly disagree to $7=$ strongly agree). The media richness construct was measured with five items that were developed based on the concepts of media richness and MRT principles (Daft \& Lengel, 1984). Customer trust constructs were measured using four items, customer commitment was measured using seven items and customer loyalty had nine items. All the items were adapted from Morgan and Hunt (1994), as well as Saini and Singh (2020).

Descriptive statistical analysis was carried out using the IBM SPSS version 22 (IBM Corp, Armonk, NY, USA) to delineate respondents' demographics, purchasing characteristics and media usage in frequency and percentages. Inferential statistical analysis was conducted through the PLS-SEM technique using the SmartPLS 3.0 software (SmartPLS GmbH, Boenningstedt, Germany) to evaluate the reflective measurement model and structure models. The reflective measurement model is a type of measurement model in which the direction of the arrows was from the construct to the indicator (Hair et al., 2014). It assumed that the measurement of the indicator was caused by the construct. With reference to that, this study developed a reflective measurement model where all indicators in the research framework were formed by constructs.

Four criteria had to be met in the reflective measurement model, namely (1) internal consistency (Cronbach Alpha and composite reliability above 0.7$)$; (2) indication of reliability (factor loading above 0.708); (3) convergent validity [Average Variance Extracted (AVE) value greater than 0.5]; and, (4) discriminant validity (cross loading, Fornell-Larcker criteria and the value of the Heterotait-Monotrait Ratio of Correlations (HTMT) ratio greater than 0.90) (Hair et al., 2014). The structural model measurement was made based on the Variance Inflation Factor value of less than five $(\mathrm{VIF}<5)$; beta $(\beta)$ value, $\mathrm{SE}$ value, and t-value greater than 1.645 (one-tailed); $\mathrm{p}$ value of less than 0.05 ; and, a confidence interval (CI) of $95 \%$. The structural model was also presented similar to the research conceptual framework through the use of beta $(\beta)$ and $\mathrm{R}^{2}$ values.

\section{Result and Discussion}

The outcome of the analysis conducted on the 295 respondents revealed, among others, that most of them were females $(58.6 \%)$ compared to males (41.4\%), with an average age of 28 . As this study focused on members of the communities of educational institutions, most of the respondents were students of higher-learning institutions $(54.2 \%)$, while of the rest were staff and academics $(45.8 \%)$. The analysis on the computer products that were purchased showed that the respondents' mainly bought laptops $(63.7 \%)$, followed by printers $(34.0$ $\%)$, netbooks (6.7\%), desktop computers $(4.6 \%)$ and tablets $(3.2 \%)$. Majority of the respondents integrated social media $(36.9 \%)$ with the services of a salesperson $(35.5 \%)$ and flyers $(6.8 \%)$ to obtain initial information about their purchase.

The analysis also illustrated that majority of respondents had integrated information gained from the salesperson at the shop $(52.9 \%)$ with social media $(32.2 \%)$ and flyers $(6.2 \%)$ to enhance their understanding about computer products. The explanation behind this was that print media such as flyers did not play a meaningful role in the customers' 
knowledge-building process and their purchase decision. Social media was an important initial media that disseminated an array of information about products, but not effective in developing customers' attitude and purchasing behaviours. However, the integration of information gained from a salesperson did increase the customers' trust to make a purchase.

\section{Evaluation of the Reflective Measurement Model}

The evaluation of the reflective measurement model showed that all constructs clearly fulfilled the criteria. The Cronbach alpha $(\alpha)$ and composite reliability (CR) values for each construct were found to be more than the required minimum level. All the constructs also demonstrated convergent validity since their AVE values were more than 0.5 . The evaluation of the discriminant validity based on the cross-loading value had proven that the discriminant validity was obtained as all indicators were loaded in its right construct. The discriminant validity evaluation based on the FornellLarcker criteria was achieved when the square root of the AVE value for each construct was greater than the correlation coefficient between construct value ( $\sqrt{ }$ AVE $>$ r) (Hair et al., 2014). This indicated that the construct was unique and different from others. Meanwhile, the HeterotraitMonotrait (HTMT) ratio criteria confirmed that the construct was unique based on the correlation coefficient between construct value that was less than 0.90 (HTMT. $\left._{90}<0.90\right)$ (Hair et al., 2014).

\section{Structural Model Evaluation}

The collinearity evaluation based on the Variance Inflation Factor (VIF) found that all predictive variables had VIF value of less than five, with the highest at 1.237 for the commitment construct. The finding showed that there was no collinearity between constructs in the structural model. The significant evaluation was carried out through a bootstrapping operation based on $t$ value that was more than $1.645(t>1.645)$ to test the one-tailed hypotheses $(\mathrm{p}<0.05)$ (Hair et al., 2014). The analysis found that all the predictive constructs positively and significantly affected the endogenous constructs.

H1, which was media richness positively and significantly affects customer trust, was accepted. This finding was in tandem with Liu et al. (2014), Sudaria et al. (2019) and Kaur et al. (2020), which was that customer trust would be easily built when product information was communicated through media that had high hierarchy of richness. It was also found that an individual's cognitive and affective trust would increase when the communicative process took place through media that had a high hierarchy of richness. $\mathrm{H} 2$, which is that media richness also positively and significantly affects customer loyalty, was also accepted. This finding supported previous studies that posited customers' desires and action to remain loyal to a business were due to the ability of a salesperson to satisfy their needs, and the impact of WOM and online reviews (Popp et al., 2015).

Specifically, $\mathrm{H} 1$ and $\mathrm{H} 2$ explained that the integration of information from different kinds of media might positively and significantly affect customer trust and loyalty. This finding demonstrated that the integration of information, which the customer gathered from flyers, social media and the help of a salesperson, might influence their trust to purchase computer products and build loyalty to the business (Daft \& Lengel, 1984). This study, based on the principles of MRT, suggested that the integration of presence information with face-to-face media was more credible and able to clarify uncertainties and equivocality of information, thus enhancing the customers' knowledge and understanding. 
This is underscored by the descriptive analysis that suggested social media to be meaningful avenues for customers to obtain initial information about computer products. However, they also indicated a preference to integrate the information with more information from a salesperson to enhance their understanding and clarify uncertainties.

H3 found that customer trust positively and significantly affected customer commitment, while $\mathrm{H} 4$ demonstrated that customer trust could positively and significantly affect their loyalty. Research carried out by Saini and Singh (2020) argued that the individual's trust would affect emotions and increase the customer's confidence in building a commitment to the business. Customers with high trust would continue to engage the same business, provide positive WOM, reduce conflicts, build long-term relationships and remain committed for a long time (Molinillo et al., 2017; Kim et al., 2020).

Lastly, H5, which is customer commitment affects customer loyalty positively and significantly, was accepted. Studies conducted by Han et al. (2018) and Kim et al. (2020) also acknowledged that the increase in customer commitment was also spurred by their loyalty to a business. Customers who are highly committed tended to hold on to the relationship in the long run by providing positive WOM, recommending the business to other customers and cooperating in promotional activities. Table 1 presents the summary of the hypotheses testing that detailed out the path coefficients' significance between constructs.

Table 1: A Summary of hypotheses testing

\begin{tabular}{clccccc}
\hline Hypo & \multicolumn{1}{c}{ Relationship } & $\mathrm{b}$ & $\mathrm{t}$ & $\mathrm{P}$ & $95 \% \mathrm{CI}$ & Results \\
\hline H1 & Media Richness -> Trust & 0.225 & 4.058 & $0.000^{*}$ & {$[0.108,0.337]$} & Accepted \\
H2 & Media Richness -> Loyalty & 0.062 & 1.824 & $0.043^{*}$ & {$[0.008,0.131]$} & Accepted \\
H3 & Trust -> Commitment & 0.399 & 6.752 & $0.000^{*}$ & {$[0.287,0.505]$} & Accepted \\
H4 & Trust -> Loyalty & 0.133 & 2.963 & $0.003^{*}$ & {$[0.047,0.224]$} & Accepted \\
H5 & Commitment -> Loyalty & 0.756 & 18.402 & $0.000^{*}$ & {$[0.677,0.831]$} & Accepted \\
\hline
\end{tabular}

Note: *Significant at 0.05 level $(\mathrm{p}<0.05)$

Figure 2 illustrates the structural model that showed the significant relationship between constructs.

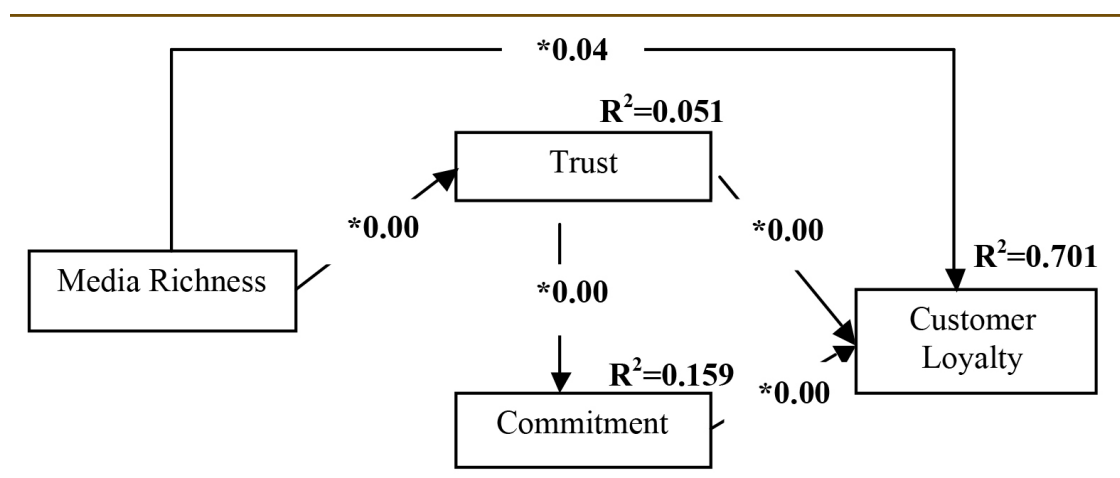

Note: *Significant at 0.05 level $(\mathrm{p}<0.05)$

Figure 2: Structural model that shows significant relationship between constructs. 


\section{Recommendation for Further Research}

The application of Media Richness Theory in this study was limited to investigating the effect of the integration of richness from printed media, social media and face-toface communication on customer attitude and behaviour. This study also focused on customer loyalty to a computer store in the purchase of computer-related products. Further studies are recommended to extend the media richness concept in a much bigger business scope and consider different types of products to vary its description. Since this study applied only the cross-sectional research design and employed PLS-SEM to test the hypotheses, it is felt that a longitudinal design through Multilevel Structural Equation Modelling (MSEM) would produce more robust and detailed findings, which would be particularly helpful in understanding the phases of customer loyalty.

\section{Conclusion}

The integration of media richness was significant as an antecedent of developing customer trust, commitment and loyalty. The analyses conducted found that through the combination of media richness, trust and commitment contributed $70.1 \%$ of variances $\left(R^{2}=0.701\right)$ on customer loyalty, with commitment being the most important contributor. In terms of theory, this study expanded MRT through the integration of media in different categories. The information gathered by consumers from every type of media would help them make the right purchase decision. In practical terms, the research findings might help a business to understand consumer behaviour regarding purchase decisions and, thus, nurturing their customers' loyalty through social media marketing.

This research is part of a dissertation which was submitted as partial fulfillment to meet requirement for the degree of Doctor of Philosophy at Universiti Utara Malaysia.

\section{References}

Berezan, O., Yoo, M., \& Christodoulidou, N. (2016). The impact of communication channels on communication style and information quality for hotel loyalty programs. Journal of Hospitality and Tourism Technology, 7(1), 100-116.

Bulut, Z. A., \& Karabulut, A. N. (2018). Examining the role of two aspects of eWOM in online repurchase intention: An integrated trust-loyalty perspective. Journal of Consumer Behaviour, 17(4), 407-417.

Casado-Diaz, A. B., Andreu, L., Beckmann, S. C., \& Miller, C. (2020). Negative online reviews and webcare strategies in social media: Effects on hotel attitude and booking intentions. Journal of Current Issues in Tourism, 23(4).

Daft, R. L., \& Lengel, R. H. (1984). Information richness: A new approach to managerial behavior and organization design. In Staw, B. M., \& Cummings, L. L. (Ed.), Research in organizational behavior (191-233).

Day, G. S. (1969). A two dimensional concept on brand loyalty. Journal of Advertising Research, 9(3), 29-35.

Giao, H. N. K., Vuong, B. N., Quan, T. N. (2020). The influence of website quality on consumer's e-loyalty through the mediating rolw of e-trust and e-satisfaction: An evidence from online shopping in Vietnam. Uncertain Supply Chain Management, 8(2), 351370.

Gruner, R. L., Vomberg, A., Homburg, C., \& Lukas, B. A. (2019). Supporting new product launches with social media communication and online advertising: Sales volume and profit implications. The Journal of Product Innovation Management, 36(2), 172-195. 
Hair, J. F., Black, W. C., Babin, B. J., Anderson, R. E., \& Tatham, R. L. (2006). Multivariate data analysis. (6th ed). Upper Saddle River, NJ: Pearson University Press.

Hair, J. F., Hult, G. T. M., Ringle, C. M., \& Sarstedt, M. (2014). A primer on partial least squares structural equation modeling (PLS-SEM). California: SAGE.

Han, H., Nguyen, H. N., Song, H., Chua, B. L., Lee, S., \& Kim, W. (2018). Drivers of brand loyalty in the chain coffee shop industry. International Journal of Hospitality Management, 72, 86-97.

Iglesias, O., Markovic, S., \& Rialp, J. (2019). How does sensory brand experience influence brand equity? Considering the roles of customer satisfaction, customer affective, commitment, and employee empathy. Journal of Business Research, 96 (March 2019), 343-354.

Kaur, H., Paruthi, M., Islam, J., \& Hollebeek, L. D. (2020). The role of brand community identification and reward on consumer brand engagement and brand loyalty in virtual brand communities. Telematics and Informatics, 46.

Khoa, B, T. (2020). The antecedents of relationship marketing and customer loyalty: A case of the designed fashion product. Journal of Asian Finance, Economics and Business, 7(2), 195204.

Kim, K., Choi, H. J., \& Hyun, S. S. (2020). Coffee house consumers' value perception and its consequences: Multidimensional approach. Sustainability, 12(4), 1663-2020.

Lee, H. N., Lee, A. S., \& Liang, Y. W. (2019). An empirical anlaysis of brand as symbol, perceived transaction value, perceived acquisition value and customer loyalty using structural equation medeling. Sustainability, 11(7).

Liu, J., Rau, P. L. P., \& Wendler, N. (2014). Trust and online information-sharing in close relationships: A cross-cultural perspective. Behaviour \& Information Technology. doi.org/10.1080/014492 9X.2014.937458.

Mainardes, E. W., \& Cardoso, M. V. (2019). Effect of the use of social media in trust, loyalty and purchase intention in physical stores. The International Review of Retail, Distribution and Consumer Research, 29(4), 456-477.

Molinillo, S., Gomez-Ortiz, B., PerezAranda, J., \& Navarro-Garcia, A. (2017). Building customer loyalty: The effect of experiential state, the value of shopping, and trust and perceived valued of service on online clothes shopping. Clothing and Textiles Research Journal, 35(3), 156-171.

Morgan, R. M., \& Hunt, S. D. (1994). The commitment-trust theory of relationship marketing. Journal of Marketing, 58(3), 20-38.

Nguyen, N., Leclerc, A., \& LeBlanc, G. (2013). The mediating role of customer trust on customer loyalty. Journal of Service Science and Management, 6, 96-109.

Ou, W. M., Shih, C. M., \& Chen, C. Y. (2015). Effects of ethical sales behavior on satisfaction, trust, commitment, retention and words-of-mouth. International Journal of Commerce and Management, 25(4), 673-686.

Popp, B., Wilson, B., Horbel, C., \& Woratschek, H. (2015). Relationship building through Facebook brand 
pages: The multifaceted roles of Sudaria, S. A., Tarofder, A. K., Khatibi, identification, satisfaction and A., \& Tham, J. (2019). Measuring perceived relationship investment. Journal of Strategic Marketing. doi:10. 1080/0965254X.2015.1095226.

Saini, S., \& Singh, J. (2020). Managing consumer loyalty. International Journal of Asian Business and Information Management, 11(1), 21the critical effect of marketing mix on customer loyalty through customer satisfaction in food and beverage products. Management Science Letters, 9, 1385-1396. 47.

Yang, D. J., \& Wu, M. J. (2014). Does customer trust play a mediating role between salesperson competence and performance? International Journal of Management, Economic and Social Sciences, 3(2), 100-121. 
